\title{
THE ROLE OF RENEWABLE ENERGIES IN THE NEW EU MEMBER STATES
}

\author{
Robert Magda \\ Szent Istvan University, Hungary and North-West University, South Africa \\ Natanya Meyer \\ University of Johannesburg, South Africa \\ Norbert Bozsik \\ Eszterhazy Karoly University, Hungary
}

\begin{abstract}
This article provides an overview of the structure and utilization of the new EU member states' (EU-13) energy consumption. During the analysis, it was determined which non-renewable energy carriers were replaced by renewables ones. The replacement of energy sources with each other was analyzed by means of a correlation matrix. Results indicated that coal was replaced by renewable energies in Poland, Czech Republic, Slovakia, Bulgaria and Cyprus. Furthermore, renewables replaced oil in Malta and gas was replaced by renewables in Lithuania. In other countries, the relation between renewables and nonrenewables could not be detected. The structure of energy production in the EU countries was different due to the differences of natural endowments. The main goal of the European Union energy policy is to reduce $\mathrm{CO} 2$ emission by decreasing fossil fuel consumption and finding new ways to replace traditional energy sources is of utmost importance.
\end{abstract}

Keywords: correlation matrix, energy consumption, new EU member states, Sankey diagram

DOI: http://dx.doi.org/10.15549/jeecar.v8i1.536

\section{INTRODUCTION}

In recent decades, global economic growth was significant due to the low cost of natural resources used for production and transportation. Today, only a few regions in the world are producing fossil fuels. The political situation in most of these regions is unstable.
Therefore, these regions are fairly uncertain sources of energy (Harangi-Rakos et al., 2017). With the growth of the world's population, energy consumption is significantly increasing, mainly in the fast-growing Asian and African regions, especially China, which has become the world's largest energy consumer ( $\mathrm{Li}$ et al., 2017). In addition to growing production and the 
change in lifestyles - especially in developed countries - energy demand has also increased (Fodor, 2012). The improvement of energy efficiency reduces the growing demand for energy; however, renewable energy has become a key issue to partially replace the fossil energy. The European Union has contributed greatly to the growth of the sector of renewable energy in Europe with the Europe 20/20/20 targets setting the midterm policy framework and by means of a variety of programs and tools providing funding and support for regional development (Pawliczek \& Zimmermannova, 2018). The role of renewable energy is significant; even if renewables are often available in smaller quantities, production cannot be regulated and some of them depend on weather conditions.

\section{Energy situation in the European Union}

The primary energy production of the European Union amounted to 755 Mtoe in 2016, which was a $15 \%$ drop compared to a decade before in 2006. The composition of primary energy production varies widely among the countries. In the EU, coal accounted for $19 \%$, oil for $10 \%$, natural gas for $14 \%$, renewables for $28 \%$ and nuclear energy for $29 \%$ of the primary energy production in 2016. The oil and gas production, as well as the refining capacity of the EU, have decreased more rapidly than energy demand in the last few years, which has resulted in negative consequences for energy security (Honvari, 2015). As a result of the decline in domestic production, the EU had to rely increasingly on primary energy imports to meet this demand. The EU consumed 1483 Mtoe import energy in 2016; meanwhile, it exported 579 Mtoe of energy. The EU is the world's largest energy importer; $53 \%$ of all energy was imported, amounting to 350 billion euros, in 2016. There are several EU members states which depend to a great extent on some suppliers, which makes them vulnerable. Russia has been the largest importer of crude oil and natural gas for the EU as well as the main supplier of solid fuel. Import dependency is also demonstrated by the fact that the total gas imports of six member states depend on one external supplier. The transport sector relies on $94 \%$ of petroleum products and $90 \%$ of them come from import. The most significant energy consumers are Germany (19.3\%), France (15.1\%), United Kingdom (11.5\%), Italy (9.4\%) and Spain (7.5\%).

Figure-1: The Development of European Union's gross inland consumption (Mtoe)

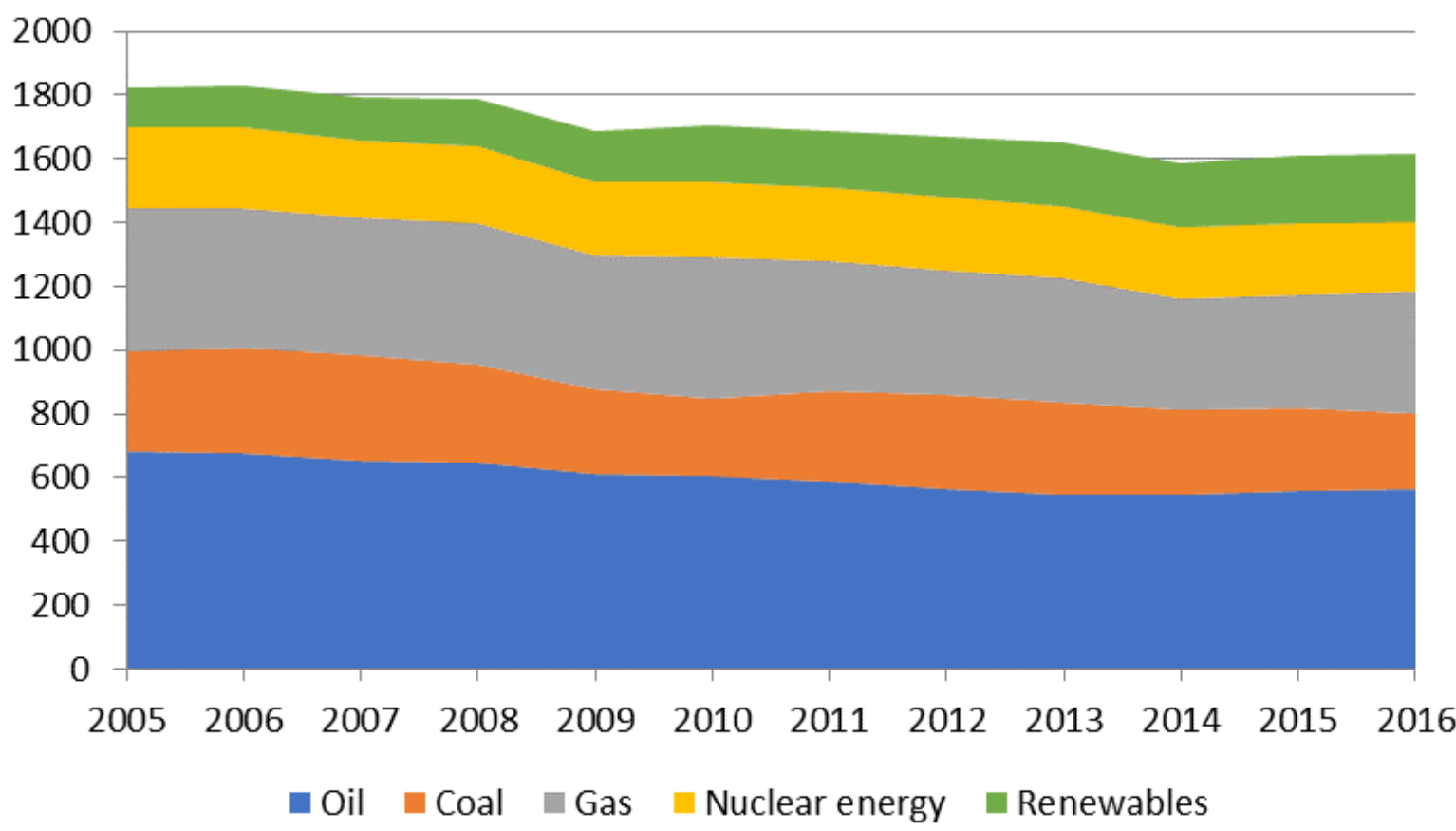

Source: own edit based on British Petroleum (2018) statistical review of world energy 
The gross inland consumption of the European Union decreased by $10 \%$ from 1822 Mtoe to 1618 Mtoe between 2006 and 2016. Meanwhile, the final energy consumption decreased from 1193 Mtoe to 1107 Mtoe, which is a 7.2\% decrease. Fossil fuels are dominant in the European Union's gross energy consumption and account for $73.2 \%$ of energy consumption. Oil represented 34.7\% (561 Mtoe), natural gas 23.7\% (383 Mtoe), and coal products $14.9 \%$ (241 Mtoe) in consumption during 2016. The importance of non-fossil fuels is much smaller in the European Union. Nuclear energy accounted for $13.4 \%$ (217 Mtoe) in total energy consumption (Figure 1 ).

The EU's renewable energy consumption reached 217 Mtoe in 2016. The biomass had the largest share with $45 \%$, followed by hydropower (14\%), wind power (12\%), biogas (8\%), biodiesel (5\%), municipal waste (5\%), solar PV (4\%), geothermal energy (3\%) and solar energy (2\%). In the EU, renewables represent $29.6 \%$ of electricity, $7.1 \%$ of transport and $19.1 \%$ of heating and cooling. Between 2006 and 2016, an opposite tendency could be observed in energy consumption within the EU. The consumption of fossils decreased by $17.8 \%$ and nuclear energy by $15.8 \%$, however the consumption of renewable energies increased by $78 \%$. Renewable energy is the only type of energy which volume and share have been steadily increasing in total energy consumption.

\section{REVIEW OF LITERATURE}

Hydropower, wind, solar, and biomass energy are even more expensive than fossil-based power generation. However, due to steadily declining reserves of fossils and rising energy prices, it is increasingly worthwhile to switch to renewable energy sources (Popp, 2013, Popp et al., 2018a, Popp et al., 2018b). The renewable energy growth around the world continues to be driven by a combination of targeted public policy and advances in energy technologies. The policy support for renewable energy focuses primarily on power generation, with support for renewable technologies lagging in the heating and cooling as well as transport sectors (REN21, 2018; Magda et al., 2019).

The utilization of renewable energy sources has an increasing role in the EU's climate and energy policy. By using more renewables to meet its energy needs, the European Union lowers its dependency on imported fossil fuels and ensures that energy production is more sustainable. Influenced by economic and environmental interests, the European Union committed itself to increase the utilization of renewable energy sources by the end of the 1990s. The Energy Policy White Paper issued by the European Commission initiated a common Renewable Energy Strategy and set up an Action Plan during 1997. The indicative objective was $12 \%$ share for the contribution by renewable sources of energy to the European Union's gross inland energy consumption by 2010 (European Commission, 1997). Recognizing the growing dependence on imports, the European Commission defined the objectives of energy policy in the Green Paper in 2006. Three key energy policy objectives were identified: improved competitiveness, security of supply, and protection of the environment (Commission of the European Communities, 2006). The Directive 2009/28/EC established an overall policy for the production and promotion of energy from renewable sources in the EU. The directive set a binding target of $20 \%$ final energy consumption from renewable sources by 2020 to be achieved through the attainment of individual national targets. Each EU country must have shown what actions they would intend to take to meet their renewables targets (including sectorial targets for electricity, heating and cooling, and transport). The countries must also ensure that at least $10 \%$ of their transport fuel comes from renewable sources by 2020 .

The European Council set even more ambitious goals by increasing commitments by 2030 . The aim was to promote the EU to achieve a more competitive, secure, and sustainable energy system. The EU countries agreed on a new renewable energy target of at least $27 \%$ of EU's final energy consumption, a $40 \%$ cut in greenhouse gas emissions compared to 1990 levels. A target for improved energy efficiency at EU level of at least $27 \%$ by 2030 was set. The European Commission aimed to increase the proportion of renewables in gross final energy consumption by 2050 to between 55\% and 75\%. This, along with energy efficiency, is considered critical in any model that could be adopted (Hernández et al., 2017). 
In comparison with traditional energy production, renewable energy production is not yet competitive under current market conditions, due to the high technology investment costs and to environmental effects of externalities not being adequately reflected in market prices. Therefore, support is needed for renewable energy production (Fodor, 2012). The development of renewable energy is important from the viewpoint of lowering the cost of imported energy, borne by Central European countries. In addition, it would help to achieve the aims of reducing $\mathrm{CO}_{2}$ emissions (Piwowar et al., 2017. Many illusions are related to the widespread use of renewable energy resources. However, the low emission of harmful byproducts is making them attractive. It is true for the application of biomass which is neutral to $\mathrm{CO}_{2}$ emission regarding the whole production cycle (Szabo \& Kiss, 2014).

The EU policy on energy aims to ensure security of energy supply in the member states, to promote energy efficiency and energy saving, as well as to increase the share of renewable energy. Solidarity among the member states is fundamental. However, each country is responsible for its own energy security. The spread of renewables may be impeded by the availability of fossil resources within a country (e.g. UK, Poland). The factors that provide the framework for countries are as follow: different international obligations, differences in planning/licensing cultures, public awareness concerning renewables, and/or technical differences (Reiche \& Bechberger, 2004).

\section{RESEARCH METHODOLOGY}

In this article, we analyze the gross inland energy consumption of the new EU member states. The gross inland energy consumption represents the quantity of energy necessary to satisfy inland consumption of the geographical entity. Thus, it represents the sum of primary energy production and net import (importexport). In a broad sense, it is supplemented with recovered products, variations of stocks, bunkers and direct use. The energy flow can be illustrated by the Sankey diagram (Figure 2), where the direction of flow is shown by the arrows and the width of the arrows is shown proportionally to the flow quantity.

Figure-2: Simplified Sankey Diagram for energy flow

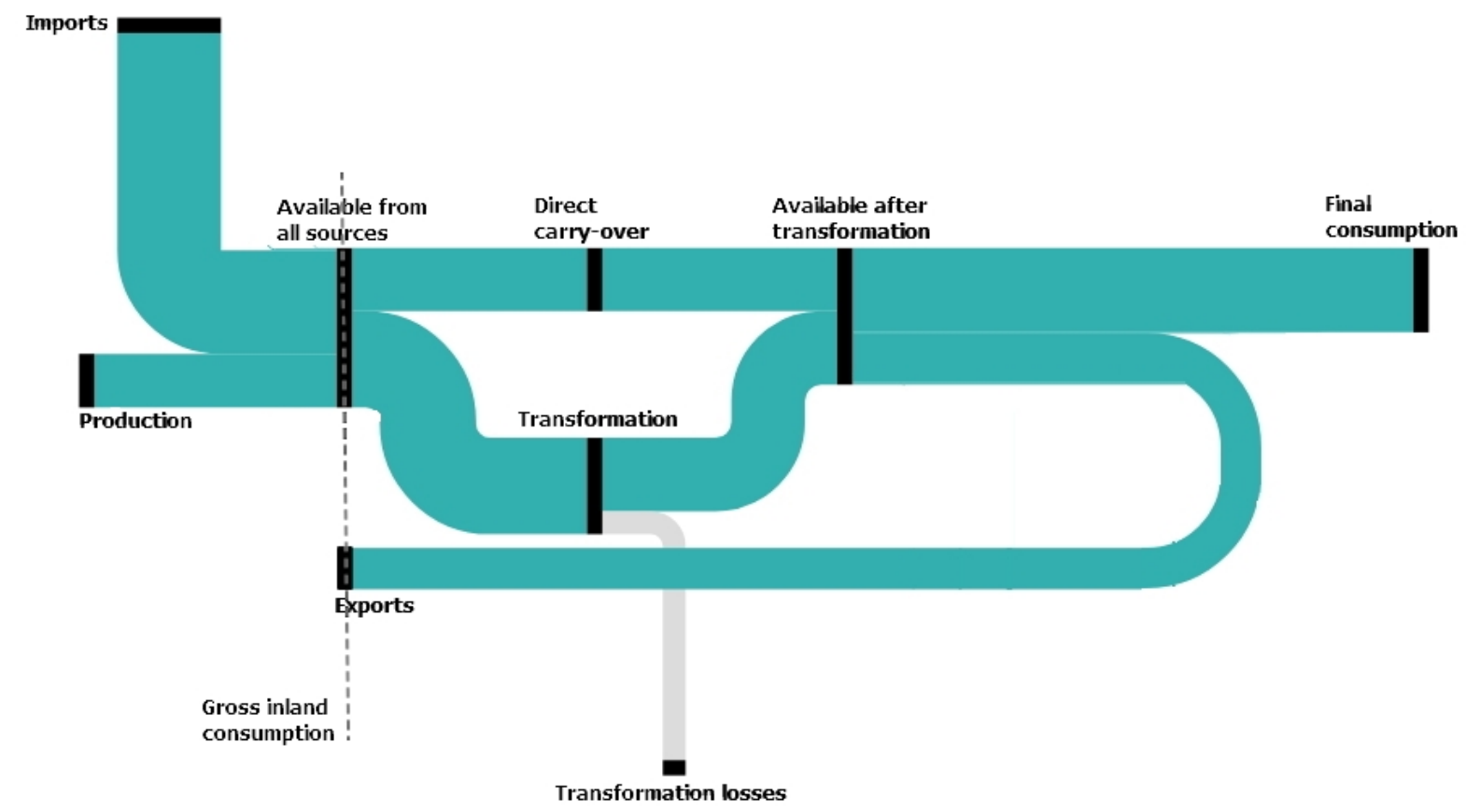

Source: Designed by the authors based on Eurostat (2019)

Figure 2 is "simplified" because it does not indicate the network loss or the energy 
consumption of the system (transformation, transport, etc.), but only the transformation loss. However, the results are not affected by these factors. The data used in the analysis were obtained from the database of the European Commission Eurostat and the International Renewable Energy Agency (IRENA) for the period between 2010 and 2016.

In the study, we used comparative time series analysis. The purpose of the article was to analyze the gross inland energy consumption of the new EU member states and to examine the relationship between renewable energy and non-renewable energy sources. During the analysis, we tried to determine which nonrenewable energy carrier was replaced by the renewables in the new EU member states. The replacement of energy sources with each other was analyzed by using a correlation matrix and it was evaluated at 5\% significance level. Then, we applied partial correlation analysis under control variables to decide whether the relationship calculated in the correlation matrix exists or not. The evaluation was conducted using IBM SPSS Statistics 20, GRETL 2018a, and MS-Office Excel 2016.

\section{RESULTS AND DISCUSSION}

For the European Union as a whole, the analysis of the relationship between renewables and non-renewable energy sources showed the following results. The values of the correlation matrix (Table 1) showed that the growth of renewable energy was due to the decrease of nuclear energy (-0.9635), coal (-0.7692) and oil (0.7733 ). Natural gas proved to be out of the $95 \%$ confidence interval. The partial correlation calculation based on control variables showed that the relation between renewables and coal, as well as renewables and oil could not be detected. However, the relation between renewables and nuclear energy could be detected. It can be stated that in the European Union the renewables have mainly replaced nuclear energy.

In the case of Bulgaria, renewables showed significant linear correlation with coal $(-0,8089)$. It was confirmed by the partial correlation test for the three control variables (oil, natural gas and nuclear energy). In Bulgaria, renewables basically replaced coal. In the case of the Czech Republic, the situation is clear regarding the relation between renewables and nonrenewable energy sources. Only the renewablescoal relation was relevant. The other three nonrenewable energy types proved to be out of the $95 \%$ confidence interval. It was confirmed by the partial correlation test, in case, when oil, natural gas and nuclear energy were the control variables. In the Czech Republic renewables replaced coal. In the case of Estonia, the renewables showed weak significant linear correlation with gas $(-0,6586)$ at $10 \%$ significance level. It must be noted that the renewables showed positive correlation with oil $(+0,8552)$.

In the case of Croatia, there is no significant linear correlation between the renewables and non-renewables. Cyprus revealed that the renewables showed significant linear correlation with coal $(-0,8044)$. The renewables replaced coal in Cyprus. In the case of Latvia, the renewables showed weak significant linear correlation with gas $(-0,6996)$ at $10 \%$ significant level. Lithuania revealed that the renewables were in negative correlation with gas $(-0,8910)$, which is confirmed by the results of the partial correlation matrix. It can be concluded that renewables replaced gas in Lithuania. Hungary was the only country among those included in the analysis where the renewables did not show significant correlation with any non-renewable resource. The highest correlation value $(-0.5800)$ was for coal, however the replacement of renewables for coal was not proved. In the case of Hungary, none of the non-renewable energy types could be detected to have been replaced by the renewables. In the case of Malta, the renewable energy had a negative correlation with the only non-renewable (the oil) $(-0.8762)$, so renewables replaced oil in Malta.

Poland indicated that renewable energy was in negative correlation with coal (-0.8547) and in positive correlation with natural gas $(+0.7826)$. Oil proved to be out of the 95\% confidence interval, which makes it not relevant. Poland did not consume nuclear energy. The partial correlation calculation showed that the negative correlation decreased between the renewables and coal when natural gas was the control variable. Therefore, the natural gas consumption affects the renewables-coal relation. However, to 
what extent renewables replace coal could not be detected. Based on the analysis, it can be concluded that both natural gas and renewables replaced coal in Poland. In the case of Romania, the renewables were in negative correlation with coal (-0.8486) and with natural gas (-0.8128). However, it was not proved by partial correlation calculation. In the case of this country, it could not be detected which non-renewable energy types were replaced by the renewables, but certainly not by crude oil. Slovenia showed no significant correlation between renewables and non-renewables. Furthermore, in the case of Slovakia, the renewables were in negative correlation with coal (-0.8659) and with natural gas (-0.7719), which was proved only for coal by partial correlation calculation (but only partially). In Slovakia, renewables replaced mainly coal during the examined period (Table 1).

Table-1: Correlation matrix of replacement of non-renewable energies for renewables

\begin{tabular}{lcccc}
\hline Countries & Coal & Oil & Natural gas & Nuclear energy \\
\hline EU-28 & $-0,7692$ & $-0,7733$ & $-0,7442$ & $-0,9635$ \\
\hline Bulgaria & $-0,8089$ & 0,5292 & 0,2779 & $-0,3427$ \\
\hline $\begin{array}{l}\text { Czech } \\
\text { Republic }\end{array}$ & $-0,9467$ & $-0,6256$ & $-0,7115$ & $-0,2352$ \\
\hline Estonia & $-0,5009$ & 0,8552 & $-0,6586$ & - \\
\hline Croatia & $-0,706$ & $-0,4538$ & $-0,3581$ & - \\
\hline Cyprus & $-0,8044$ & $-0,7078$ & - & - \\
\hline Latvia & $-0,6250$ & $-0,3134$ & $-0,6996$ & - \\
\hline Lithuania & $-0,5912$ & 0,7814 & $-0,8910$ & - \\
\hline Hungary & $-0,5800$ & $-0,2838$ & $-0,5163$ & $-0,2221$ \\
\hline Malta & - & $-0,8762$ & - & - \\
\hline Poland & $-0,8547$ & $-0,3778$ & 0,7823 & - \\
\hline Romania & $-0,8486$ & 0,0006 & $-0,8128$ & $-0,3240$ \\
\hline Slovenia & $-0,3296$ & $-0,3945$ & $-0,2414$ & 0,0617 \\
\hline Slovakia & $-0,8659$ & $-0,3999$ & $-0,7719$ & $-0,2670$ \\
\hline
\end{tabular}

Source: Authors own calculation.

Concerning the results, it should be noted that the non-renewable energy sources were clearly separated, but the renewables were examined holistically. Regarding the composition, the renewables can be very different by countries. The biomass is the dominant renewable energy in each country; however, some member states have other renewable sources with higher rates than the average of the EU (e.g., the wind in Poland, biogas in the Czech Republic, or hydropower in Slovakia).

\section{CONCLUSION}

The structure of energy production of the new EU member states was different due to the differences of natural endowments. However, the results showed that renewables replaced mainly coal. Most countries were highly dependent on oil and natural gas. The main goal is to reduce the consumption of fossil energy and to replace them by renewables in the future. Reduction of oil consumption could be achieved by increasing consumption of biofuels and by 
using more electric or hybrid power devices. Natural gas used for heating can be replaced by biomass, solar and geothermal energy. Coal, which is mainly responsible for environmental damage can be replaced by biomass; in case of electric power generation, coal can be replaced by hydropower, wind or solar energy. In addition to increasing the share of renewable energy, the EU also emphasized improvement of energy efficiency (savings). During the examined period, the decrease of energy consumption was affected not only by the negative impact of the 2008 crisis, but also by the spread of efficient consumers (e.g. more energy-efficient motors, passive houses, modernization of light technics etc.). Although this study added some valuable insights on the topic of renewable energy, it is not without its limitations. One of the main limitations is the data set including data only till 2016. Future studies may include using longer timed data sets and included more counties to the analysis to determine if similar results in foe example more western countries exist.

\section{REFERENCES}

British Petroleum (2018). Statistical Review of World Energy.

https://www.bp.com/en/global/corporate/e nergy-economics/statistical-review-ofworld-energy/downloads.html Date of access: 2018/10/12

Commission of the European Communities (2006). Green Paper. A European Strategy for Sustainable, Competitive and Secure Energy.

http://europa.eu/documents/comm/green_p apers/pdf/com 2006_105_en.pdf Date of access: 2019/04/12

European Commission (1997). Communication from the Commission energy for the future: renewable sources of energy. White Paper for a Community Strategy and Action Plan. http://europa.eu/documents/comm/white_p apers/pdf/com97_599_en.pdf Date of access: 2019/04/22

Eurostat (2019). Sankey diagram.

Fodor, B. E. (2012). Promoting the Use of Renewable Energies. An Evaluation of the Hungarian Feed-in Tariff System. PhD
Dissertation. Corvinus University of Budapest

Harangi-Rákos, M., Popp, J. and Oláh, J., 2017. Global outlook of world biofuels production. Journal of Central European Green Innovation, 5(4): 13-31.

http:/greeneconomy.unieszterhazy.hu/sites/ greeneconomy.foiskola.krf/files/upload/JCEGI _2017_5_4_2.pdf Date of access: 2018/10/12

Hernández, L., Burriel, J. R., Bujdosó, Z., Topliceanu, L. (2017). Training needs in renewable energies for local development. http://repositori.uji.es/xmlui/bitstream/han dle/10234/167300/02_

Training\%20needs\%20in\%20RES\%20for\%20lo cal\%20development_En.pdf?sequence $=4$ Accessed: 2019/06/22

Honvári, P. (2015). Success or failure? The utilization possibilities of the renew-able energy sources in the countries of the Visegrad Group. In Berkes, J., Kecskés P. (Ed.) Távol és közel, az elmúlt 25 év területi folyamatai, szerkezetei, intézményei, ahogy az új generáció látja. A IX. Fiatal Regionalisták Konferenciájának előadásai. Győr (pp. 69-79). https://ec.europa.eu/eurostat/web/energy/e nergy-flow-diagrams Date of access: 2019/06/23

Li, N., Kang, R., Feng, Ch., Wang, Ch., Zhang, Ch. (2017). Energy structure, economic growth, and carbon emissions: evidence from Shaanxi province of China (1990-2012), Forum Scientiae Oeconomia, 5(1): 79-93. DOI: 10.23762/fso_vol5no1_7

Magda, R., Bozsik, N. \& Meyer, N. (2019). An evaluation of gross inland energy consumption of six central European countries. Journal of Eastern European and Central Asian Research, 6(2): 270-281. doi:https://doi.org/10.15549/jeecar.v6i2.291

Pawliczek, A., Zimmermannova, J. (2018). Evaluation of the economic indicators of a company - prosumer using photovoltaics, Forum Scientiae Oeconomia, 6(4), 51-64. DOI: 10.23762/FSO_VOL6_NO4_4

Piwowar, A., Olanszka, A., Rezny, L. (2017). Development of Renewable Energy in the Visegrad Ccountries - Comparative Analysis. 
in International Scientific Conference Hradec Economic Days 2017, At Hradec Králové, Czech Republic, pp. 695-705.

Popp, J. (2013). The role of bioenergy in the global energy supply. Gazdálkodás Scientific Journal, 57(5): 419 - 435.

Popp, J., Kot, S., Lakner, Z., Oláh, J. (2018a). Biofuel use: peculiarities and implications. Journal of Security and Sustainability Issues, 7(3): 477-493.

Popp, J., Oláh, J., Fekete Farkas, M., Lakner, Z., Máté, D. (2018b). The Relationship Between Prices of Various Metals, Oil and Scarcity, Energies, 11(9), 2392, 1-19.

Reiche, D., Bechberger, M. (2004). Policy differences in the promotion of renewable energies in the EU member states. Energy Policy, 32(7), $843-849$.

REN21 (2019). Renewables 2018 Global Status Report 2018. http://www.ren21.net/gsr2018/ Date of access: 2019/06/23.

Szabo, M., Kiss, Á. (2014). Effects of renewable energy resources on the landscape. Hungarian Geographical Bulletin, 63(1): 516.

\section{ABOUT THE AUTHORS}

Natanya Meyer, email: natanyam@uj.ac.za

Dr. Robert Magda is an associate professor, at Szent István University, Faculty of Economics and Social Sciences, Institute of Economics, Law and Methodology and an extraordinary associate professor at School of Management Sciences Faculty of Economic and Management Sciences, North-West University, South Africa. He has a $\mathrm{PhD}$ in Economic Science and a Habilitated Doctorate in Management and Business Administration. During his research activities he has gained insight into several fields of research, which include but are not limited to the following: the examination of land as a natural and economic resource; the economic potentials of rural areas; limited resources and sustainability.

Dr. Natanya Meyer is an Associate Professor of Entrepreneurship in the SARChI Chair Entrepreneurship Education at the
University of Johannesburg, South Africa. She completed her B. Com and Honours degree in Economics and Risk Management and thereafter her Master's degree in Development and Management and $\mathrm{PhD}$ in Entrepreneurship. Her research focuses on entrepreneurial and economic related topics with a focus on females, youth, and the enabling environment. She is a reviewer, editorial board and scientific committee member for several national and international journals and has collaboration links with various Asian and east European universities.

Dr. Norbert Bozsik is a college professor at Eszterházy Károly University, Faculty of Economics and Social Sciences, Department of Management. He has a PhD in Management and Business Administration from Szent István University. During his research activities he focused on several fields of research, which are the following: analysis of the European food trade, analysis of energy consumption of Visegrad countries, efficiency of agricultural production, labour productivity in the Hungarian food industry. In these research areas he published a series of publications with his colleagues and students, both in domestic and international periodicals, journals and books. 